\title{
Dependence of calcification on light and carbonate ion concentration for the hermatypic coral Porites compressa
}

\author{
F. Marubini ${ }^{1, *}$, H. Barnett ${ }^{1}$, C. Langdon ${ }^{2}$, M. J. Atkinson ${ }^{3}$ \\ ${ }^{1}$ Columbia University Biosphere 2 Center, Oracle, Arizona, USA \\ ${ }^{2}$ Lamont-Doherty Earth Observatory, Palisades, New York 10964, USA \\ ${ }^{3}$ HIMB, PO Box 1346, 46-007 Lilipuna Road, Kanehoe, Hawaii 96744, USA
}

\begin{abstract}
Temperature, light and aragonite saturation state of seawater are important determinants of the global distribution of coral reefs. Saturation state of surface seawater is decreasing in response to increases in atmospheric $\mathrm{pCO}_{2}$, causing concern for a global reduction in the rates of reef accretion. In this study we address the influences of light and saturation state on skeletal growth of the hermatypic coral Porites compressa. We conducted 2 experiments using coral nubbins; one in a controlled laboratory with Biosphere 2 ocean water and the other in the $711 \mathrm{~m}^{2}$ Biosphere 2 ocean itself. The laboratory experiment consisted of 3 light treatments $\left(\mathrm{PAR}=698,150,81 \mu \mathrm{mol}\right.$ photons $\mathrm{m}^{-2}$ $\mathrm{s}^{-1}$ ) and 2 chemical treatments $\left(\mathrm{pCO}_{2}=199 \mu \mathrm{atm}, \Omega=5.05, \mathrm{CO}_{3}{ }^{2-}=355 \mu \mathrm{mol} \mathrm{\textrm {kg } ^ { - 1 }}\right.$; and $\mathrm{pCO}_{2}=$ $448 \mu \mathrm{atm}, \Omega=2.48, \mathrm{CO}_{3}{ }^{2-}=183 \mu \mathrm{mol} \mathrm{kg}{ }^{-1}$ ). In the Biosphere 2 ocean, coral nubbins were deployed at 4 depths $(6,4,2$ and $0.5 \mathrm{~m})$ which corresponded to different light conditions (PAR from 2.7 to $29.5 \mathrm{~mol}$ photons $\mathrm{m}^{-2} \mathrm{~d}^{-1}$ ) during 3 different chemical states, mimicking the conditions of the Last Glacial Maximum (LGM), the present day and the year 2100 (Y2100). Calcification rate changed with light following the typical hyperbolic tangent function. Calcification rate was positively correlated with saturation state, which ranged from 5 (LGM) to 2.4 (Y2100). From the glacial experimental conditions $\left(\Omega=5.05, \mathrm{pCO}_{2}=186\right)$ to those of the future $\left(\Omega=2.25, \mathrm{pCO}_{2}=641\right)$, calcification dropped by $30 \%$; from present day conditions $\left(\Omega=3.64, \mathrm{pCO}_{2}=336\right)$ to those of the future, calcification dropped by $11 \%$. This decrease in calcification rate occurred at all light levels, indicating that rising $\mathrm{CO}_{2}$ will impact corals living at all depths.
\end{abstract}

KEY WORDS: Coral $\cdot$ Calcification $\cdot$ Photosynthesis $\cdot$ Light $\cdot\left[\mathrm{CO}_{3}{ }^{2-}\right] \cdot \mathrm{pCO}_{2} \cdot$ Aragonite saturation state

Resale or republication not permitted without written consent of the publisher

\section{INTRODUCTION}

Coral reefs are restricted to latitudes where the annual minimum seawater temperature exceeds $18^{\circ} \mathrm{C}$ (Vaughan 1919, Achituv \& Dubinsky 1990). There are 2 other environmental variables however that correlate with reef development (Kleypas et al. 1999): light and saturation state of aragonite. Light is strongly influenced by latitude and depth, and on a local scale, can be strongly attenuated by particulate matter and dis-

*Present address: Observatoire Océanologique Européen, Centre Scientifique de Monaco, Avenue Saint-Martin, MC-98000 Monaco.E-mail: fmarubini@yahoo.com solved organics in the water column. Light fuels the high primary productivity of coral reefs and enhances the precipitation of $\mathrm{CaCO}_{3}$ skeletons in hermatypic corals (Falkowski et al. 1990) and coralline algae (Johansen 1981). Saturation state of aragonite $\left(\Omega_{\text {arago- }}\right.$ nite, the $\mathrm{CaCO}_{3}$ mineral phase deposited by scleractinian corals and green calcareous algae), is proportional to the product of the concentrations of $\mathrm{Ca}^{2+}$ and $\mathrm{CO}_{3}{ }^{2-}$ ions in seawater (Stumm \& Morgan 1981) but as the concentration of $\mathrm{Ca}^{2+}$ remains nearly constant, $\Omega$ is proportional to the $\mathrm{CO}_{3}{ }^{2-}$ ion concentration. $\Omega$ is also strongly correlated with latitude and while it remains nearly constant throughout the latitude belt where corals thrive, it decreases almost 3-fold from the tropics 
to the poles (Kleypas et al. 1999), largely as a function of the effect of temperature on the solubility of $\mathrm{CO}_{2}$. Locally, $\Omega$ can be markedly affected by biological, physical and chemical processes on reefs (i.e. photosynthesis, calcification, water residence time, freshwater inputs etc.); Broecker \& Takahashi (1966) in the Bahama Banks and Smith \& Pesret (1974) in the Fanning Island lagoon found $\Omega$ to be as low as half that of adjacent oceanic water. Suzuki et al. (1995) reported a diurnal change in $\Omega$, from as low as 1.7 at night to as high as 5.3 during the day, on a fringing reef in the Ryukyu islands of Japan. Furthermore, the rate of inorganic and/or biogenic $\mathrm{CaCO}_{3}$ precipitation on reef lagoons has been observed to be proportional to $\Omega$ (Broecker \& Takahashi 1966, Smith \& Pesret 1974), introducing the possibility that $\Omega$ controls calcification, and thus reef accretion. The relationship between $\Omega$ and reef growth is of particular importance in view of the observed increase in atmospheric $\mathrm{CO}_{2}$ (Smith \& Buddemeier 1992). In water, dissolved $\mathrm{CO}_{2}$ is hydrated to form $\mathrm{H}_{2} \mathrm{CO}_{3}$ in continuous equilibrium with $\mathrm{HCO}_{3}{ }^{-}$ and $\mathrm{CO}_{3}{ }^{2-}$, the proportion of each carbon species being dependent on $\mathrm{pH}$ at any temperature and salinity. An elevation in $\mathrm{CO}_{2}$ results in a decrease in $\mathrm{pH}$ and thus a decrease in $\mathrm{CO}_{3}{ }^{2-}$ and $\Omega$. As $\mathrm{CO}_{2}$ in surface seawater equilibrates with air, it has been predicted that by the year 2100, when $\mathrm{pCO}_{2}$ in air will double its present value, $\Omega$ will be reduced in the tropics by up to $30 \%$ (Kleypas et al. 1999). A direct relationship between $\Omega$ and ecosystem calcification rate has been recently demonstrated in a long-term, large-scale experiment with an artificial algal-dominated reef community (Langdon et al. 2000) and in a short-term, small-scale coral mesocosm experiment (Leclercq et al. 2000). In a first extrapolation of these results to the global scale, worldwide reef calcification was predicted to decrease by $8 \%$ to $17 \%$ over the next century (Kleypas et al. 1999). The increase in temperature that is coupled to the increase in $\mathrm{CO}_{2}$ will also have an effect on global reef accretion. Thus future predictions of climate change on coral reefs should consider the effects of both temperature and saturation state.

At the organism level, calcification in hermatypic corals is an active process carried out by the calicoblastic epithelium and strongly influenced by the photosynthetic activity of the symbiotic zooxanthellae (see review by Gattuso et al. 1999). Interactions between photosynthesis and calcification stem from the fact that both processes utilise dissolved inorganic carbon (DIC) from seawater and $\mathrm{CO}_{2}$ from cellular respiration (Pearse 1970, Allemand et al. 1998a, Furla et al. 2000). Goreau \& Goreau (1959) proposed that the removal of $\mathrm{CO}_{2}$ by photosynthesis increases $\mathrm{pH}$, in turn promoting $\mathrm{CO}_{3}{ }^{2-}$ availability and precipitation. Kühl et al. (1995) measured a shift in pH from 7.5 to 8.5 in the boundary layer of corals exposed to dark and light conditions respectively, giving a local increase in $\mathrm{CO}_{3}{ }^{2-}$. Given that there is a large change in internal $\mathrm{pH}$ of coral cells due to photosynthesis, it is not clear to what extent diel changes in $\mathrm{pH}$ and $\Omega$ in the external seawater affect coral calcification. Marubini \& Atkinson (1999) showed that a decrease in seawater $\mathrm{pH}$ inhibits calcification in Porites compressa, but the conditions tested ( $\mathrm{pH} 8.0$ vs $\mathrm{pH} 7.2$ and $\Omega 1.81$ vs $\Omega 0.28$ ) were far more extreme than any real world scenario. Gattuso et al. (1998) showed that a reduction in $\Omega$ inhibits calcification in Stylophora pistillata; however, while $\Omega$ in surface seawater is affected by changes in $\left[\mathrm{CO}_{3}{ }^{2-}\right]$, they changed $\Omega$ by changing $\left[\mathrm{Ca}^{2+}\right]$, which has been constant at $10 \mathrm{mM}$ in surface seawater since the Precambrian (Kempe \& Kazmierczak 1994). Thus, the available data support the hypothesis that calcification is controlled by seawater $\Omega$, but they are not sufficient to provide an accurate prediction of future scenarios (Gattuso et al. 1999). In order to supplement our understanding of how hermatypic corals will respond to the increase in anthropogenic $\mathrm{CO}_{2}$, we present a study that focuses on the response of coral calcification to changes in the carbon moiety of $\Omega$ of a magnitude relevant to global change scenarios. In particular, we chose the conditions measured at the time of the Last Glacial Maximum as the highest saturation state, and those as predicted for the year 2100 as the lowest saturation state. We compared the effect of $\Omega$ on calcification with that of light, because calcification is strongly affected by photosynthesis.

\section{MATERIALS AND METHODS}

Preparation of corals. Branches of Porites compressa were cut from adjacent colonies growing at 1 to $2 \mathrm{~m}$ depth at Point Reef, Coconut Island, Kanehoe Bay, Hawaii. Care was taken to choose branches with tips of similar shape and orientation to light. Tips were prepared into coral 'nubbins' as described in Davies (1995); tips were cut to size, ground flat, and glued with SuperGlue on acrylic tiles $(30 \times 30 \mathrm{~mm})$. Coral nubbins were air freighted overnight to the Biosphere 2 Center of Columbia University, Arizona, where all experiments took place. The Biosphere 2 Center houses a self-sustaining tropical reef biota in a large $\left(2650 \mathrm{~m}^{3}\right)$ seawater tank (hereafter refered to as 'B2Ocean') (Atkinson et al. 1999). Being a closed system at constant temperature, the B2Ocean is very amenable to long-term experimental manipulations in seawater DIC chemistry (Langdon et al. 2000). Weekly additions of $\mathrm{NaOH}, \mathrm{HCl}_{2} \mathrm{NaHCO}_{3}$ and $\mathrm{Na}_{2} \mathrm{CO}_{3}$ and bimonthly additions of $\mathrm{CaCl}_{2}$ ensure constant alkalinity, DIC and $\Omega$ levels. The coral nubbins 
arrived 2 wk prior to the beginning of each experiment, and were held at $0.5 \mathrm{~m}$ depth in the B2Ocean for recovery.

Measurement of skeletal parameters. Coral skeletal weight was measured weekly by buoyant weighing (Davies 1989). A standard density determination kit was fitted to a Mettler balance with a precision of $0.1 \mathrm{mg}$. Corals were grown for $6 \mathrm{wk}$ in each experiment. We wished to compare growth of corals characteristic of each different light and chemical condition, therefore it was important that corals adapted completely to the new conditions before they were considered for growth rate estimation. Growth rate decreased in the low light treatments during the first $3 \mathrm{wk}$ of the experiment as the corals acclimated to decreased light intensity. Thus final skeletal growth rates were obtained from regression equations of weight against time over the last $3 \mathrm{wk}$ of the experiment only. At the end of each experiment, nubbin height and average diameter were measured using calipers with $0.2 \mathrm{~mm}$ precision. Surface area was calculated assuming that each nubbin comprises a cylinder surmounted by a half sphere (Rinkevich \& Loya 1983).

Seawater analysis. Total alkalinity (TA) was measured potentiometrically with an automated titrator and computed using the Gran equation (Dickson \& Goyet 1994, Langdon et al. 2000). The concentration of DIC was measured coulometrically (Chipman et al. 1993). The components of the carbonate system $\left(\mathrm{pCO}_{2}\right.$, $\mathrm{HCO}_{3}{ }^{-}, \mathrm{CO}_{3}{ }^{2-}$ ) were calculated from TA and DIC using the apparent dissociation constants of Mehrbach et al. (1973) for carbonic acid and of Dickson (1990) for boric acid. $\mathrm{Ca}^{2+}$ was determined by potentiometric titration (Kanamori \& Ikegami 1980). The aragonite saturation state was calculated according to Mucci (1983). Dissolved inorganic nutrients were analysed following Technicon Standard Methods on a Technicon Autoanalyzer II (Walsh 1989).

Growth experiment in controlled laboratory setup. A 2-factor design was used to study the combined effect of saturation state and light. The factor ' $\Omega$ ' had 2 levels: high and low. The factor 'Light' had 3 levels: high, medium and low. A set of 60 nubbins was randomly divided into 6 groups, each of which was randomly assigned to a treatment, and grown in a 91 glass aquarium for $6 \mathrm{wk}$. Seawater from B2Ocean was pumped into a $100 \mathrm{l}$ header tank. Water from the header tank was split into 2 separate pipes, supplying 3 chambers each. Inflow rate was $21 \mathrm{~min}^{-1}$ to ensure short water residence time $(<5 \mathrm{~min})$, fast mixing and strong water motion in each chamber. Water overflowed from the aquaria into the flow-through constant temperature water-bath. Temperature was constant at $26.2 \pm 0.3^{\circ} \mathrm{C}$. At the time of this experiment, seawater from B2Ocean was maintained at a high saturation state to mimic chemical conditions characteristic of the Last Glacial Maximum (LGM) (target values: $\Omega=5.6$; $\left.\mathrm{pCO}_{2}=200 \mu \mathrm{atm}\right)$. Thus no extra chemical addition was necessary for the high saturation state treatment $(\mathrm{H} \Omega)$. The low saturation state treatment $(\mathrm{L} \Omega)$, representing $\Omega$ values similar to those predicted for the year 2100 (target values: $\Omega=2.4 ; \mathrm{pCO}_{2}=700 \mu \mathrm{atm}$ ) was achieved by continuously dripping a $0.1 \mathrm{~N}$ solution of $\mathrm{HCl}$ via a peristaltic pump into the pipe from the header tank. Seawater samples for TA and DIC were collected biweekly from each treatment. Light was provided $12 \mathrm{~h} \mathrm{~d}^{-1}$ by a set of 4 overhead metal halide lamps $\left(1000 \mathrm{~W}, 4000^{\circ} \mathrm{K}\right.$ BT37 bulb). Three different light treatments were achieved by increasing the height of the lamps above the chambers. Total photosynthetically available radiation (PAR) was measured in situ with an underwater spherical light meter (QSI200, Biospherical Instruments Inc.) in each chamber. The high light treatment (HL), medium light treatment (ML) and low light treatment (LL) received an average of $698 \pm 39,150 \pm 2.1$, and $81 \pm 3.5 \mu \mathrm{mol}$ photons $\mathrm{m}^{-2} \mathrm{~s}^{-1}$ and thus a daily average of $30,6.5$ and $3.5 \mathrm{~mol}$ photons $\mathrm{m}^{-2} \mathrm{~d}^{-1}$ respectively.

Growth experiment in B2Ocean. The seawater in the B2Ocean was experimentally manipulated to provide 3 consecutive $10 \mathrm{wk}$ periods representing the carbon chemistry characteristic of the LGM, present day (PD) and the year 2100 (Y2100). Target values for TA

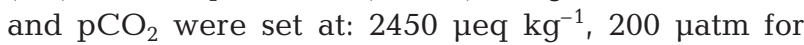
LGM; $2300 \mu \mathrm{eq} \mathrm{kg}^{-1}, 360 \mu \mathrm{atm}$ for PD; and $2300 \mu \mathrm{eq}$ $\mathrm{kg}^{-1}, 700$ uatm for Y2100. Seawater samples were collected twice a day for analyses. Chemicals to bring concentrations back to target levels were added once a week. At the beginning of each chemical regime, nubbins of Porites compressa were shipped from Hawaii. After the initial 2 wk recovery period, 12 nubbins were randomly assigned to 4 different depths $(0.5,2,4$, $6.5 \mathrm{~m})$ for $6 \mathrm{wk}$, along the fore-reef slope of the B2Ocean. They were held on acrylic trays on cement blocks and protected from grazing fish by a $10 \mathrm{~mm}$ mesh cage. PAR was collected at 5 min intervals by an underwater spherical lightmeter (Li-Cor LI-193SB) placed next to the shallowest group. A coefficient of extinction was calculated from instantaneous light measurement at the surface and at $6.5 \mathrm{~m}$ depth taken with a portable meter (QSI-200, Biospherical Instruments Inc.). Corals at 2, 4 and $6.5 \mathrm{~m}$ received 60, 30 and $5 \%$ of the light at $0.5 \mathrm{~m}$ respectively.

Statistical analyses. The effect of $\mathrm{pH}$ and light on coral growth rate was tested for each experiment by 2 -way ANOVA. Calcification rate per nubbin was positively correlated to final surface area in both laboratory (Pearson's $r=0.476, p<0.001$ ) and B2Ocean experiments (Pearson's $r=0.471, \mathrm{p}<0.001$ ), so surface 
area of each nubbin was used to normalise growth data. Calcification rates were not normally distributed until transformed with a square root function. ANOVAs were performed on square root transformed data to fit all assumptions of normality and homogeneity of variance. All statistical analyses were performed using MINITAB 12.2 (Minitab Inc., State College, PA). The response curve for calcification rate versus light was modelled using a hyperbolic tangent function as suggested by Chalker (1981). Data were fitted by the Gauss-Newton least-square method.

\section{RESULTS}

\section{Growth experiment in controlled laboratory setup}

DIC was approximately the same in both treatments $\left(\mathrm{H} \Omega, 1932 \mu \mathrm{mol} \mathrm{kg}{ }^{-1}\right.$; L $\left.\Omega, 1871 \mu \mathrm{mol} \mathrm{kg}{ }^{-1}\right)$. The acid lowered $\mathrm{pH}_{\mathrm{SW}}$ from 8.31 in $\mathrm{H} \Omega$ to 7.97 in $\mathrm{L} \Omega, \mathrm{pCO}_{2}$ correspondingly increased from 186 to $440 \mu \mathrm{atm}$, and $\left[\mathrm{CO}_{3}{ }^{2-}\right]$ decreased from 373 to $183 \mu \mathrm{mol} \mathrm{kg}{ }^{-1}$. $\Omega$ decreased from 5.05 to 2.48 (Table 1). Average initial weight of nubbins was $1.52 \pm 0.43 \mathrm{~g}$. Surface area was $8.42 \pm 1.85 \mathrm{~cm}^{2}$. Maximal growth rate was obtained in the high light and high $\Omega$ treatment (HL-H $\Omega$ ) with an average skeletal accretion rate of $1.94 \mathrm{mg} \mathrm{CaCO}_{3} \mathrm{~cm}^{-2}$

Table 1. Chemical conditions for laboratory experiment. Data given as means \pm SD for duration of experiment

\begin{tabular}{|lcc|}
\hline Variable & High $\Omega$ & Low $\Omega$ \\
\hline $\mathrm{TA}\left(\mu \mathrm{eq} \mathrm{kg}{ }^{-1}\right)$ & $2462 \pm 90$ & $2132 \pm 87$ \\
$\mathrm{DIC}\left(\mu \mathrm{mol} \mathrm{kg}{ }^{-1}\right)$ & $1932 \pm 53$ & $1871 \pm 48$ \\
$\mathrm{pCO}_{2}(\mu \mathrm{atm})$ & $186 \pm 93.6$ & $440 \pm 94.8$ \\
$\mathrm{CO}_{3}{ }^{2-}\left(\mu \mathrm{mol} \mathrm{kg}{ }^{-1}\right)$ & $373 \pm 58$ & $183 \pm 33$ \\
$\mathrm{HCO}_{3}{ }^{-}\left(\mu \mathrm{mol} \mathrm{kg}^{-1}\right)$ & $1554 \pm 81$ & $1675 \pm 36$ \\
$\left.\mathrm{CO}_{2}(\mu \mathrm{mol} \mathrm{kg})^{-1}\right)$ & $5.1 \pm 0.7$ & $12 \pm 2$ \\
$\mathrm{pH}_{\mathrm{SW}}$ & $8.31 \pm 0.10$ & $7.97 \pm 0.08$ \\
$\mathrm{Ca}^{2+}\left(\mathrm{mmol} \mathrm{kg}^{-1}\right)$ & $9.0 \pm 0.3$ & $9.0 \pm 0.3$ \\
$\Omega_{\text {aragonite }}$ & 5.05 & 2.48 \\
\hline
\end{tabular}

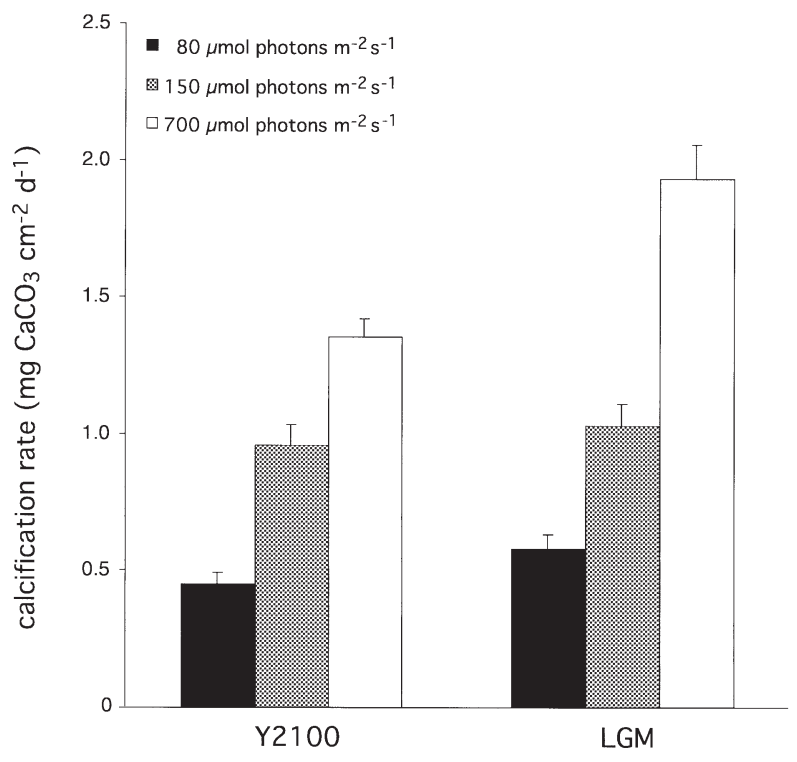

Fig. 1. Porites compressa. Daily calcification rate $\left(\mathrm{mg} \mathrm{CaCO}_{3}\right.$ $\mathrm{cm}^{-2} \mathrm{~d}^{-1}$ ) in laboratory. Effect of $\Omega_{\text {arag }}$ (for LGM: $\Omega_{\text {aragonite }}=$ 5.05, for Y2100: $\Omega_{\text {aragonite }}=2.48$ ) studied under 3 different light regimes. Results given as means and SE

$\mathrm{d}^{-1}$. Conversely, nubbins growing in the low light and low $\Omega$ treatment (LL-L $\Omega$ ) had the lowest growth rate, at only $0.45 \mathrm{mg} \mathrm{CaCO}_{3} \mathrm{~cm}^{-2} \mathrm{~d}^{-1}$ (Table 2). A 2-way ANOVA found both light and $\Omega$ to have a highly significant effect on growth rate (light: $F_{2,52}=94.95$, p < $\left.0.001 ; \Omega: F_{1,52}=13.36, \mathrm{p}=0.001\right)$. The magnitude of the effect of $\Omega$ was not constant in all light treatments (Fig. 1), rather it increased with increasing light and this resulted in the interaction term becoming significant (ANOVA $F_{2,52}=3.38, \mathrm{p}=0.05$ ).

\section{Growth experiment in B2Ocean}

For each experimental period, TA and $\mathrm{pCO}_{2}$ were maintained, on average, within 1 and $10 \%$ of target values respectively. Accordingly, $\left[\mathrm{CO}_{3}{ }^{2-}\right]$ varied from

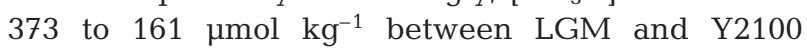

Table 2. Porites compressa. Mean initial mass, surface area and skeletal growth rate in laboratory. Effect of $\Omega_{\text {arag }}$ (for LGM: $\Omega_{\text {aragonite }}=5.05$, for Y2100: $\Omega_{\text {aragonite }}=2.48$ ) on calcification rate was studied under 3 different light regimes. Data given as means $\pm \mathrm{SE}$

\begin{tabular}{|c|c|c|c|c|c|c|}
\hline Treatments & $\begin{array}{c}\text { Irradiance } \\
\left(\mu \mathrm{mol} \text { photons } \mathrm{m}^{-2} \mathrm{~s}^{-1}\right)\end{array}$ & $\Omega_{\text {aragonite }}$ & $\mathrm{n}$ & $\begin{array}{l}\text { Initial mass } \\
\qquad(\mathrm{g})\end{array}$ & $\begin{array}{l}\text { Surface area } \\
\left(\mathrm{cm}^{2}\right)\end{array}$ & $\begin{array}{c}\text { Growth } \\
\left(\mathrm{mg} \mathrm{cm}^{-2} \mathrm{~d}^{-1}\right)\end{array}$ \\
\hline HL-H $\Omega$ & 698 & 5.05 & 10 & $1.53 \pm 0.12$ & $8.58 \pm 0.68$ & $1.94 \pm 0.06$ \\
\hline HL-L $\Omega$ & 698 & 2.48 & 10 & $1.64 \pm 0.11$ & $9.36 \pm 0.33$ & $1.36 \pm 0.12$ \\
\hline $\mathrm{ML}-\mathrm{H} \Omega$ & 150 & 5.05 & 10 & $1.50 \pm 0.14$ & $8.71 \pm 0.83$ & $1.03 \pm 0.08$ \\
\hline ML-L $\Omega$ & 150 & 2.48 & 10 & $1.48 \pm 0.12$ & $8.23 \pm 0.45$ & $0.96 \pm 0.07$ \\
\hline LL-H $\Omega$ & 81 & 5.05 & 10 & $1.58 \pm 0.20$ & $8.12 \pm 0.63$ & $0.58 \pm 0.05$ \\
\hline LL-L $\Omega$ & 81 & 2.48 & 9 & $1.36 \pm 0.11$ & $7.40 \pm 0.37$ & $0.45 \pm 0.04$ \\
\hline
\end{tabular}


Table 3. B2Ocean experiment. Seawater carbon and nutrient chemistry and light intensity are given for each treatment. Data given as means $\pm \mathrm{SD}$ for duration of experiment

\begin{tabular}{|c|c|c|c|}
\hline $\begin{array}{l}\text { Variables: } \\
\text { Period: }\end{array}$ & $\begin{array}{c}\text { LGM } \\
\text { Feb-Mar }\end{array}$ & $\begin{array}{c}\text { PD } \\
\text { May-Jun }\end{array}$ & $\begin{array}{c}\text { Y2100 } \\
\text { Aug-Sep }\end{array}$ \\
\hline \multicolumn{4}{|l|}{ Carbon chemistry } \\
\hline TA $\left(\mu\right.$ eq $\left.\mathrm{kg}^{-1}\right)$ & $2462 \pm 90$ & $2336 \pm 51$ & $2290 \pm 39$ \\
\hline DIC $\left(\mu \mathrm{mol} \mathrm{kg}{ }^{-1}\right)$ & $1932 \pm 53$ & $1980 \pm 30$ & $2074 \pm 52$ \\
\hline $\mathrm{pCO}_{2}$ ( $\left.\mu \mathrm{atm}\right)$ & $186 \pm 93.6$ & $336 \pm 82.4$ & $641 \pm 88.6$ \\
\hline $\mathrm{CO}_{3}{ }^{2-}\left(\mu \mathrm{mol} \mathrm{kg}{ }^{-1}\right)$ & $373 \pm 58$ & $252 \pm 32$ & $161 \pm 14$ \\
\hline $\mathrm{HCO}_{3}^{-}\left(\mu \mathrm{mol} \mathrm{kg}{ }^{-1}\right)$ & $1554 \pm 81$ & $1718 \pm 45$ & $1896 \pm 61$ \\
\hline $\mathrm{CO}_{2}\left(\mu \mathrm{mol} \mathrm{kg}{ }^{-1}\right)$ & $5.5 \pm 0.7$ & $10.1 \pm 0.7$ & $17.7 \pm 2.0$ \\
\hline $\mathrm{pH}_{\mathrm{SW}}$ & $8.31 \pm 0.10$ & $8.08 \pm 0.07$ & $7.82 \pm 0.05$ \\
\hline $\mathrm{Ca}^{2+}\left(\mathrm{mmol} \mathrm{kg}{ }^{-1}\right)$ & $9.0 \pm 0.3$ & $9.6 \pm 0.2$ & $9.3 \pm 0.14$ \\
\hline$\Omega_{\text {aragonite }}$ & 5.05 & 3.64 & 2.25 \\
\hline \multicolumn{4}{|c|}{ Irradiance (mol photons $\mathrm{m}^{-2} \mathrm{~d}^{-1}$ ) } \\
\hline $0.5 \mathrm{~m}$ & $18.2 \pm 1.28$ & $29.5 \pm 0.73$ & $22.1 \pm 1.28$ \\
\hline $2 \mathrm{~m}$ & 9.8 & 16.0 & 11.9 \\
\hline $4 \mathrm{~m}$ & 4.7 & 7.7 & 5.7 \\
\hline $6.5 \mathrm{~m}$ & 2.7 & 4.4 & 3.4 \\
\hline \multicolumn{4}{|l|}{ Nutrients } \\
\hline $\mathrm{NO}_{3}^{-}\left(\mu \mathrm{mol} \mathrm{kg}{ }^{-1}\right)$ & $0.3 \pm 0.01$ & $0.07 \pm 0.02$ & $0.3 \pm 0.13$ \\
\hline $\mathrm{NH}_{4}^{+}\left(\mu \mathrm{mol} \mathrm{kg}{ }^{-1}\right)$ & $0.19 \pm 0.01$ & $0.14 \pm 0.04$ & $0.38 \pm 0.05$ \\
\hline $\mathrm{PO}_{4}^{-}\left(\mu \mathrm{mol} \mathrm{kg}{ }^{-1}\right)$ & $<0.01$ & $0.013 \pm 0.006$ & $0.06 \pm 0.011$ \\
\hline
\end{tabular}

(Table 3). $\left[\mathrm{Ca}^{2+}\right]$ was lower than seawater by up to $10 \%$ and this resulted in actual $\Omega$ values being slightly lower than expected. Nutrient concentrations remained consistently low. Light varied with season, it was highest during PD and lowest during LGM (Table 3). Average initial weight of nubbins was $1.60 \pm$ $0.42 \mathrm{~g}$, and surface area was $8.24 \pm 1.50 \mathrm{~cm}^{2}$. Nubbins grown in the LGM treatment in shallow water had the highest growth rate $(1.84 \mathrm{mg}$ $\mathrm{CaCO}_{3} \mathrm{~cm}^{-2} \mathrm{~d}^{-1}$ ), and those grown for Y2100 at $4 \mathrm{~m}$ depth had the lowest growth rate $(0.6 \mathrm{mg}$ $\mathrm{CaCO}_{3} \mathrm{~cm}^{-2} \mathrm{~d}^{-1}$ ) (Table 4). Within each chemical regime, depth had a strong effect on growth rate (Fig. 2), with the nubbins growing at $0.5 \mathrm{~m}$ depth having the fastest calcification rate in all cases. Growth rate was highest during the LGM period and lowest during the Y2100 period (Fig. 2). The effects of depth and $\Omega$, tested by 2 -way ANOVA, were highly significant (light: $F_{3,126}=41.73, \mathrm{p}<$ $\left.0.0001 ; \Omega: F_{2,126}=26.62, p<0.0001\right)$. Corals grown at 0.5 and $2 \mathrm{~m}$ depth calcified significantly faster than corals grown at 4 or $6.5 \mathrm{~m}$ depth (Tukey, $\mathrm{p}<0.0001)$. The interaction term was not significant $\left(F_{5,126}=1.88, \mathrm{p}>0.05\right)$. At all depths, chemical regime had a significant effect; corals grew faster in the LGM treatment than either PD (Tukey, p = 0.0012) or Y2100 (Tukey, $\mathrm{p}<0.0001)$. Furthermore, growth in Y2100 was significantly lower than in PD (Tukey, $p=0.002$ ).

\section{Combined data}

The effects of light and $\Omega$ on the calcification rate of Porites compressa nubbins were analysed in more detail by combining the laboratory and B2Ocean data for corals grown under LGM and Y2100 conditions. As light was different for each experiment, and in order to make direct comparisons, a hyperbolic tangent function (Chalker 1981) was fitted to both sets of data (Fig. 3). We chose to force the curve through the origin as $P$. compressa nubbins would not have survived in complete darkness for the 6 wk duration of these experiments. Maximum calcification rate $\left(G_{\max }\right)$ was significantly different with $1.89 \mathrm{mg} \mathrm{CaCO}_{3}$ $\mathrm{cm}^{-2} \mathrm{~d}^{-1}( \pm 0.18)$ for LGM and $1.32 \mathrm{mg} \mathrm{CaCO}_{3}$ $\mathrm{cm}^{-2} \mathrm{~d}^{-1}( \pm 0.13)$ for Y2100. The point of intersection of the initial part of the curve with the light saturated asymptote $\left(I_{\mathrm{k}}\right)$ was $7.8 \mathrm{~mol}$ photons $\mathrm{m}^{-2}$ $\mathrm{d}^{-1}( \pm 1.6)$ for LGM and $9.0 \mathrm{~mol}$ photons $\mathrm{m}^{-2} \mathrm{~d}^{-1}$ $( \pm 2.0)$ for Y2100, which are not significantly different. Consequently the slope of the tangent to the initial part of the curve (alpha) had decreased from $2.4 \mathrm{~g} \mathrm{CaCO}_{3}$ mol photons ${ }^{-1}$ in LGM to $1.5 \mathrm{~g} \mathrm{CaCO}_{3}$ mol photons ${ }^{-1}$ in Y2100.

\section{DISCUSSION}

Data from both laboratory and B2Ocean experiments show that calcification in the hermatypic coral Porites compressa is dependent on light and on the carbonate ion concentration of seawater. Since the same result

Table 4. Porites compressa. Mean initial mass, surface area and skeletal growth rate in B2Ocean. Effect of $\Omega_{\text {aragonite }}$ (for LGM: $\Omega_{\text {aragonite }}=5.05$, for PD: $\Omega_{\text {aragonite }}=3.64$ and for Y2100: $\Omega_{\text {aragonite }}=2.25$ ) studied at 4 different depths. Data given as means $\pm \mathrm{SE}$

\begin{tabular}{|c|c|c|c|c|c|}
\hline & $\begin{array}{l}\text { Depth } \\
\text { (m) }\end{array}$ & $\mathrm{n}$ & $\begin{array}{c}\text { Initial } \\
\text { mass (g) }\end{array}$ & $\begin{array}{c}\text { Surface } \\
\text { area }\left(\mathrm{cm}^{2}\right)\end{array}$ & $\begin{array}{c}\text { Growth } \\
\left(\mathrm{mg} \mathrm{cm}^{-2} \mathrm{~d}^{-1}\right)\end{array}$ \\
\hline \multicolumn{6}{|c|}{ LGM: $\Omega_{\text {aragonite }}=5.05$} \\
\hline A & 0.5 & 12 & $1.50 \pm 0.09$ & $8.76 \pm 0.37$ & $1.84 \pm 0.16$ \\
\hline B & 2 & 12 & $1.51 \pm 0.10$ & $8.85 \pm 0.44$ & $1.64 \pm 0.09$ \\
\hline $\mathrm{C}$ & 4 & 12 & $1.54 \pm 0.11$ & $7.91 \pm 0.45$ & $1.11 \pm 0.12$ \\
\hline $\mathrm{D}$ & 6.5 & 12 & $1.73 \pm 0.15$ & $7.95 \pm 0.43$ & $1.02 \pm 0.07$ \\
\hline \multicolumn{6}{|c|}{ PD: $\Omega_{\text {aragonite }}=3.64$} \\
\hline $\mathrm{A}$ & 0.5 & 11 & $1.74 \pm 0.41$ & $8.46 \pm 0.26$ & $1.48 \pm 0.11$ \\
\hline B & 2 & 11 & $1.83 \pm 0.11$ & $8.74 \pm 0.47$ & $1.39 \pm 0.11$ \\
\hline $\mathrm{C}$ & 4 & 11 & $1.79 \pm 0.18$ & $8.57 \pm 0.51$ & $1.07 \pm 0.10$ \\
\hline $\mathrm{D}$ & 6.5 & 10 & $1.59 \pm 0.10$ & $7.48 \pm 0.36$ & $0.62 \pm 0.07$ \\
\hline \multicolumn{6}{|c|}{ Y2100: $\Omega_{\text {aragonite }}=2.25$} \\
\hline $\mathrm{A}$ & 0.5 & 12 & $1.52 \pm 0.10$ & $8.89 \pm 0.26$ & $1.33 \pm 0.11$ \\
\hline B & 2 & 12 & $1.52 \pm 0.12$ & $8.18 \pm 0.57$ & $1.02 \pm 0.08$ \\
\hline $\mathrm{C}$ & 4 & 12 & $1.39 \pm 0.11$ & $7.48 \pm 0.50$ & $0.60 \pm 0.06$ \\
\hline D & 6.5 & 12 & $1.51 \pm 0.11$ & $7.55 \pm 0.41$ & $0.67 \pm 0.06$ \\
\hline
\end{tabular}




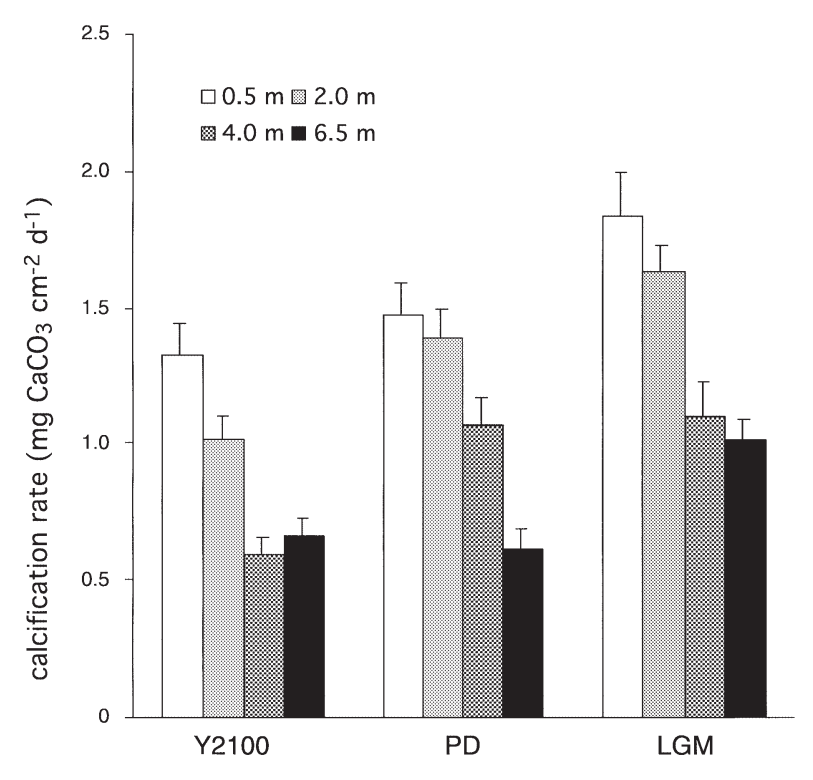

Fig. 2. Porites compressa. Daily calcification rate $(\mathrm{mg} \mathrm{CaCO}$ $\mathrm{cm}^{-2} \mathrm{~d}^{-1}$ ) in B2Ocean. Effect of $\Omega_{\text {aragonite }}$ (for Y2100: $\Omega_{\text {aragonite }}=$ 2.6 , for PD: $\Omega_{\text {aragonite }}=4.0$, and for LGM: $\Omega_{\text {aragonite }}=6.0$ ) studied at 4 different depths. Results given as means and SE

was obtained in both experiments, we are very confident in the validity of this interpretation even though each experiment on its own was limited by the pseudoreplication inherent in the experimental design.

Growth rates in this experiment are similar to previous estimates for nubbins of Porites compressa and $P$. porites grown in the laboratory (Marubini \& Davies 1996, Marubini \& Atkinson 1999, Marubini \& Thake 1999) and in the field (Edmunds \& Davies 1986, Edmunds \& Davies 1989). As weight gain is a function of colony size (Bak 1976, Jokiel et al. 1978, Vago et al. 1997), and colony size is artificially determined when nubbins are cut off the mother colony, size must be controlled for when measuring growth rate. The most common estimates of colony size are surface area (Barnes \& Taylor 1973, Rinkevich \& Loya 1984), skeletal weight (Ferrier-Pagès et al. 2000), protein (Dennison \& Barnes 1988, Allemand et al. 1998b), chlorophyll (Gattuso 1987) and tissue content (Edmunds \& Davies 1986). The choice of parameter depends on the question and level of analysis. We are interested in growth response to light and saturation state, rather than the process of growth itself; surface area is appropriate for this level of analysis since it is linearly correlated to growth rate and controls for colony size.

The large experimental differences in irradiance had a dominant effect on the calcification rate of Porites compressa in both laboratory and B2Ocean experiments. The relationship between light and calcification has been central to many physiological studies of symbiotic anthozoans (Barnes \& Chalker 1990). Light directly affects rates of photosynthesis of the coral symbionts, which in turn influences calcification. The numerous mechanisms put forward to explain the link between host calcification and symbiont photosynthesis reflect the complexity of this interaction (Allemand et al. 1998a, Gattuso et al. 1999). There are 2 temporal levels at which photosynthesis and calcification can interact: short- and long-term. In the short-term, as photosynthesis removes $\mathrm{CO}_{2}$, it raises intracellular $\mathrm{pH}$ and intracellular saturation state toward values more favourable to the deposition and crystallisation of carbonate (Goreau 1961, Chalker 1975, Johnston 1980, Gladfelter 1983, Barnes \& Chalker 1990, Allemand et al. 1998a). In the long-term, since coral calcification requires energy for organic matrix production, $\mathrm{CO}_{3}{ }^{2-}$ and $\mathrm{Ca}^{2+}$ transport etc., it is influenced by the energy status of the host, which in turn depends largely on the daily photosynthetic rate of the symbionts. The effect of light on the energy status of the whole coral symbiosis has been assessed in terms of carbon budgets by Muscatine et al. (1984). Zooxanthellae in light-adapted colonies of Stylophora pistillata translocate 5 times as much carbon as those of shade colonies and contribute to as much as $143 \%$ of the respiratory requirements of the host against a contribution of only $58 \%$ in shaded corals. We measured calcification rate over a 6 wk experimental period; therefore this measure of growth reflects the combina-

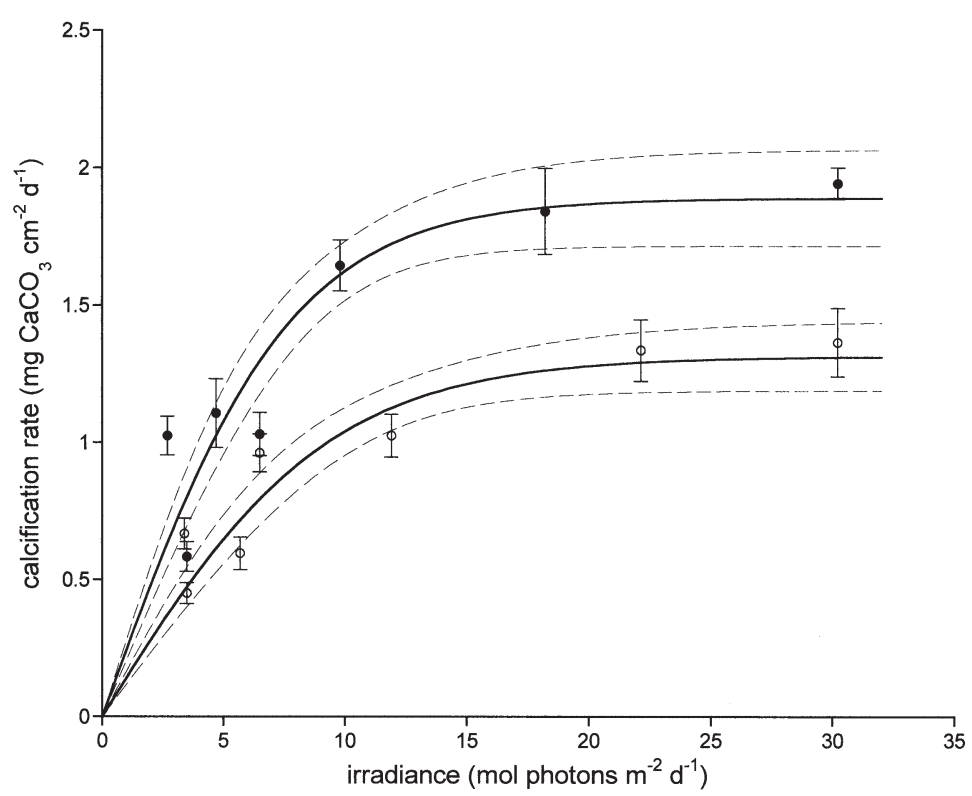

Fig. 3. Porites compressa. Daily calcification rate $\left(\mathrm{mg} \mathrm{CaCO} \mathrm{Cm}^{-2}\right.$ $\mathrm{d}^{-1}$ ) versus irradiance in laboratory and B2Ocean: low $\Omega_{\text {aragonite }}(\mathrm{O}$, Y2100); and high $\Omega_{\text {aragoniter }}(\bullet$, LGM). Data given as means and SE. Fitted lines and $95 \%$ CIs derived from hyperbolic tangent function 
tion of both instantaneous and long-term effects of photosynthesis on calcification.

Heterotrophic nutrition influences the energy status of the host and the rate of calcification in corals (Miller 1995, Grottoli \& Wellington 1999, Witting 1999). To ensure comparable energy status, corals were freshly shipped from the reef in Kanehoe Bay, Hawaii, and each batch of nubbins remained in experimental conditions for the same length of time. Heterotrophic feeding, if present, was minimal during the experiment as the planktonic population in the B2Ocean is negligible.

As light varied 10-fold (2.8/3.5 to $30.2 \mathrm{~mol}$ photons $\left.\mathrm{m}^{-2} \mathrm{~d}^{-1}\right)$ calcification rate increased 3-fold (0.45/0.67 to 1.33/1.94 mg $\mathrm{CaCO}_{3} \mathrm{~cm}^{-2} \mathrm{~d}^{-1}$ ). The relationship between light and calcification was not linear but followed a hyperbolic tangent function. Estimates from the curves in Fig. 3 show that calcification reached the asymptote at about $10 \mathrm{~mol}$ photons $\mathrm{m}^{-2} \mathrm{~d}^{-1}$. Thus as light decreased from 30.2 to $8.5 \mathrm{~mol}$ photons $\mathrm{m}^{-2} \mathrm{~d}^{-1}$, calcification rate remained constant and high. A further 3-fold decrease in light was matched by a 3-fold decrease in calcification.

A reduction in long-term calcification with depth/ shading has been measured both in terms of weight change (Gattuso \& Jaubert 1984, Yap et al. 1998) and linear extension (Buddemeier et al. 1974, Baker \& Weber 1976, Huston 1985, Logan \& Tomascik 1991). Maximum PAR in this study (700 $\mu \mathrm{mol}$ photons $\mathrm{m}^{-2} \mathrm{~s}^{-1}$ ) was less than on shallow tropical reefs (1000 to $2000 \mu \mathrm{mol}$ photons $\mathrm{m}^{-2} \mathrm{~s}^{-1}$, Schick et al. 1996), thus we are not able to comment on the potential for inhibition of calcification by extremely high light. Our application of the hyperbolic tangent function is to $6 \mathrm{wk}$ long calcification data, whereas Chalker (1981) applied it to simulate light-saturation curves for instantenous lightenhanced calcification. Although the function fits well in both cases, one could expect a change in the estimated parameters $\left(I_{\mathrm{k}}, G_{\max }\right.$ and alpha) between lightsaturation curves for instantenous and long-term calcification. In particular, the interpretation of the curve estimates is different. Estimates from instantenous light-saturation curves are built on the response of 1 individual to different light intensities and are used to describe the degree of photoadaptation of that individual. Photoadaptation to low light availability involves an increased production of photosynthetic pigments (Falkowski \& Dubinsky 1981, McCloskey \& Muscatine 1984, Porter et al. 1984), reflected in an increased photosynthetic efficiency (i.e. a higher alpha and a lower $I_{\mathrm{k}}$ ). Instantenous curves could be used to predict a response to short-term changes in light intensity (dusk/dawn; cloud cover) but not to model photosynthesis or calcification at different depths on a reef. On the contrary, curves from long-term studies are built on the response of different individuals that have already fully adapted to different light intensities and that are tested only at the light intensity they are adapted to. From these curves one can obtain valid estimates to model the relationship between calcification and depth on a reef.

We show that calcification in Porites compressa correlates well with saturation state $(\Omega)$; as $\Omega$ decreased from 5 (LGM) to 2.3/2.5 (Y2100) the estimated maximum calcification rate decreased by $30 \%$. Furthermore, the change from PD experimental conditions $\left(\Omega=3.64, \mathrm{pCO}_{2}=336\right)$ to those of treatment $\mathrm{Y} 2100(\Omega=$ 2.25 , pCO2 $=641$ ) caused an $11 \%$ reduction in calcification. All seawater carbon chemistry variables showed some difference between $\Omega$ treatments, with the most notable differences being in $\left[\mathrm{CO}_{3}{ }^{2-}\right], \mathrm{pH}$, $\mathrm{pCO}_{2}$ and $\left[\mathrm{CO}_{2}\right]$. Between LGM and Y2100 treatments, $\left[\mathrm{CO}_{3}{ }^{2-}\right]$ decreased from 373 to $161 \mu \mathrm{mol} \mathrm{kg}{ }^{-1}$ and $\mathrm{pH}$ decreased from 8.31 to 7.82. As expected, $\mathrm{pCO}_{2}$ and $\left[\mathrm{CO}_{2}\right]$ increased more than 3-fold, from 186 to $641 \mu \mathrm{atm}$ and from 5.1 to $17.7 \mu \mathrm{mol} \mathrm{kg} \mathrm{k}^{-1}$ respectively. In contrast, DIC and $\mathrm{HCO}_{3}{ }^{-}$increased by 10 to $20 \%$ only. The task is then to identify which of these variables is causing a response in calcification. $\left[\mathrm{CO}_{3}{ }^{2-}\right]$ is the prime candidate, but since the calcifying epithelium of scleractinian corals is not in direct contact with seawater, how calcification can respond to changes in seawater $\left[\mathrm{CO}_{3}{ }^{2-}\right]$ is not immediately apparent. The mechanism must be able to account for the fact that a change in seawater $\left[\mathrm{CO}_{3}{ }^{2-}\right]$ results in a change in $\left[\mathrm{CO}_{3}{ }^{2-}\right]$ in the intracellular environment. To explain these results, we suggest that $\mathrm{CO}_{3}{ }^{2-}$ diffuses freely across coral tissue. No direct evidence of $\left[\mathrm{CO}_{3}{ }^{2-}\right]$ diffusion or transport has been found (Gattuso et al. 1999), but Furla et al. (2000) did find that the transfer of DIC from an external medium to the coral skeleton is accomplished by paracellular diffusion across the oral tissue and by anion transport into the calicoblastic cells. Thus while $\mathrm{HCO}_{3}{ }^{-}$is often assumed to be the ionic species transported, $\left[\mathrm{CO}_{3}{ }^{2-}\right]$ cannot be ruled out.

Alternatively, the mechanism may be based on $\mathrm{pH}$. DIC will equilibrate intracellularly depending upon $\mathrm{pH}$, independent of the species entering the symbiosis. If cellular $\mathrm{pH}$ in proximity to the calicoblastic cells follows the $\mathrm{pH}$ in the external medium, then an increase in $\mathrm{pH}$ in seawater will result in an increase in $\mathrm{pH}$ internally, with a consequent increase in the internal availability of $\left[\mathrm{CO}_{3}{ }^{2-}\right]$. To date, no method is available to measure the $\mathrm{pH}$ within or around the calicoblastic cells in vivo. Microsensors have successfully described the chemical micro-environment in the boundary layer just above coral tissue (Kühl et al. 1995, de Beer et al. 2000). Measuring the response of the boundary layer to changes in the overlying seawater could provide some insight into the relationship between intracellular processes and external $\mathrm{pH}$. 
Although we did not measure the response of zooxanthellae photosynthesis to increased $\mathrm{pCO}_{2}$, productivity in scleractinian corals is thought to be a function of $\mathrm{HCO}_{3}{ }^{-}$rather than $\mathrm{CO}_{2}$ because $\mathrm{HCO}_{3}{ }^{-}$is the carbon species preferentially utilised in photosynthesis (Goiran et al. 1996, Allemand et al. 1998a). Furthermore zooxanthellae appear to possess a carbonconcentrating mechanism (Leggat et al. 1999). It is unlikely however that an increase in $\mathrm{pCO}_{2}$ mitigated the reduction in $\Omega$ by photosynthetic enhancement of calcification in Porites compressa because calcification was reduced by $30 \%$ while $\mathrm{pCO}_{2}$ increased 4 -fold. Thus either the increased $\mathrm{pCO}_{2}$ did not enhance photosynthesis at all, or the enhancement was too small to influence calcification and counter the negative effect of reduced $\Omega$. In comparison to changes in the other variables, the change in DIC and $\mathrm{HCO}_{3}{ }^{-}$was too small in this experiment for it to be properly addressed. Further studies should directly address the physiological mechanisms by which a decrease in $\Omega$ results in the observed reduction of calcification. In this study we focused on mass accretion, but the other parameters of calcification, such as linear extension and crystal structure, should also be addressed.

The interaction between light and $\Omega$ is interesting. A decrease in $\Omega$ is matched by a decrease in calcification at all light intensities. Similarly, Leclercq et al. (2000) found a positive correlation between calcification and $\Omega$ in a coral mesocosm both during daylight hours and during the night. The magnitude of the effect of $\Omega$ was proportional to the growth rate of Porites compressa at each light intensity. Thus, the reduction of calcification by decreased $\Omega$ was greater in high-light adapted corals than in low-light adapted corals. These observations suggest that the effect of seawater $\Omega$ on coral calcification acts as a mechanism that is not directly dependent on light or on the energy status of the coral.

Extrapolating these results to the global scale, $\mathrm{CaCO}_{3}$ deposition rate in scleractinian corals is expected to decrease by $10 \%$ over the next $100 \mathrm{yr}$, as atmospheric $\mathrm{pCO}_{2}$ will double. The effect will be observed in corals at all depths. Among the datasets that have been compiled by Gattuso et al. (1999) and those obtained since (Schneider \& Erez 2000, Leclercq 2000, Langdon \& Atkinson pers. comm.) all studies on the relationship between $\Omega$ and calcification to date are consistent with the hypothesis that biogenic calcification is influenced by the saturation state of seawater. The only difference observed between studies is one of magnitude; predictions for reduction in calcification between the present day and the year 2100 range between $3 \%$ (Gattuso et al. 1998) and 40\% (Langdon et al. 2000). On the one hand, the range in response could be artificially inflated by the high variability in experimental protocols. Among all the studies men- tioned above, one has combined organismal scale studies (single species) with ecosystem scale studies (small and large mesocosms), different taxa of calcifying organisms (corals vs algae), different coral families (Poritidae, Pocilloporidae, Acroporidae), different types of chemical manipulation (changes in $\mathrm{Ca}^{2+}, \mathrm{pH}_{1} \mathrm{pCO}_{2}$ ) and experimental durations (minutes to years). On the other hand, there is the real possibility that a large range in response is due to physiological differences between organisms. If that is the case, one should expect a large variability in the way in which different reef types and different reef calcifiers will cope and indeed are coping with increasing atmospheric $\mathrm{pCO}_{2}$.

In contrast to these manipulative studies, Lough \& Barnes (1997) found no evidence for a decrease in mass deposition in the skeletons of massive colonies of Porites over the last 2 centuries. Based on the results of the present study, one would have predicted that coral calcification has already been reduced by $10 \%$ between pre-industrial time and today. Instead they found a slight increase in calcification that was interpreted as a consequence of the increased average annual sea surface temperature (Lough \& Barnes 1999). It is possible that for massive Porites, the positive correlation between calcification and temperature can be much larger than the negative correlation between calcification and saturation state. Different coral species may, however, respond differently. Nevertheless, the results of this study unequivocally show a positive correlation between the saturation state of seawater and the calcification rate of $P$. compressa at varying light levels. The next obvious step is to focus on the interaction between temperature and saturation state, as accurate predictions of global change have to include the effects of both saturation state and temperature on coral growth.

Acknowledgements. We thank J. Flemming for collecting the corals and preparing the nubbins. We are grateful to F. Neat and W. Broecker for the many comments on drafts of this paper, and to E. Hochberg and M. Carmichael for preparing the graphs. We thank the staff and students at Columbia University Biosphere 2 Center for their generous help: N. Mager, J. Carter, J. van Harren, Boggie and his technical crew, D. Weitz, R. Goodman and A. Snyder. This research was partially funded by University of Hawaii SeaGrant award, year 32, R/CR-1.

\section{LITERATURE CITED}

Achituv Y, Dubinsky Z (1990) Evolution and zoogeography of coral reefs. In: Dubinsky Z (ed) Ecosystems of the world 25: coral reefs. Elsevier, Amsterdam, p 1-9

Allemand D, Furla P, Bénazet-Tambutté S (1998a) Mechanisms of carbon acquisition for endosymbiont photosynthesis in Anthozoa. Can J Bot 76:925-941

Allemand D, Tambutte E, Girard JP, Jaubert J (1998b) 
Organic matrix synthesis in the scleractinian coral Stylophora pistillata: role in biomineralisation and potential target of the organotin tributyltin. J Exp Biol 210: 2001-2009

Atkinson MJ, Barnett H, Anderson H, Langon C, Carpenter SJ, McConnaughey T, Hochberg E, Smith M, Marino B (1999) The Biosphere 2 Coral Reef Biome. Ecol Engin 13: 147-171

Bak RPM (1976) The growth of coral colonies and the importance of crustose coralline algae and burrowing sponges in relation with carbonate accumulation. Neth J Sea Res 10:285-337

Baker PA, Weber JN (1976) Coral growth rate: variation with depth. Earth Planet Sci Lett 27:57-61

Barnes DJ, Chalker BE (1990) Calcification and photosynthesis in reef-building corals and algae. In: Dubinsky Z (ed) Ecosystems of the world 25: coral reefs. Elsevier, Amsterdam, p 109-131

Barnes DJ, Taylor DL (1973) In situ studies of calcification and photosynthetic carbon fixation in the coral Montastrea annularis. Helgol Wiss Meeresunters 24:284-291

Broecker WS, Takahashi T (1966) Calcium carbonate precipitation in the Bahama Banks. J Geophys Res 71:1575-1602

Buddemeier RW, Maragos JE, Knutson DW (1974) Radiographic studies on reef coral exoskeletons: rates and patterns of coral growth. J Exp Mar Biol Ecol 14:179-200

Chalker BE (1975) Calcification, metabolism, and growth by the staghorn coral Acropora cervicornis (Lamarck). PhD thesis, University of Miami

Chalker BE (1981) Simulating light-saturation curves for photosynthesis and calcification by reef-building corals. Mar Biol 63:135-141

Chipman D, Marra J, Takahashi T (1993) Primary production at $47^{\circ} \mathrm{N}$ and $20^{\circ} \mathrm{W}$ in the North Atlantic: a comparison between the ${ }^{14} \mathrm{C}$ incubation method and the mixed layer carbon budget. Deep-Sea Res 40:151-169

Davies PS (1989) Short-term growth measurements of corals using an accurate buoyant weighing technique. Mar Biol 101:389-395

Davies PS (1995) Coral nubbins and explants for reef assessment and laboratory ecotoxicology. Coral Reefs 14: 267-269

de Beer D, Kühl M, Stambler N, Vaki L (2000) A microsensor study of light enhanced $\mathrm{Ca}^{2+}$ uptake and photosynthesis in the reef-building hermatypic coral Favia sp. Mar Ecol Prog Ser 194:75-85

Dennison WC, Barnes DJ (1988) Effect of water motion on coral photosynthesis and calcification. J Exp Mar Biol Ecol 115:67-77

Dickson AG (1990) Thermodynamics of the dissociation of boric acid in synthetic seawater from 273.15 to $318.15^{\circ} \mathrm{K}$. Deep-Sea Res 37:755-766

Dickson AG, Goyet C (eds) (1994) Handbook of methods for the analysis of the various parameters of the carbon dioxide system in seawater; version 2. Oak Ridge National Laboratory, Oak Ridge, TN

Edmunds PJ, Davies PS (1986) An energy budget for Porites porites (Scleractinian). Mar Biol 92:339-347

Edmunds PJ, Davies PS (1989) An energy budget for Porites porites (Scleractinian), growing in a stressed environment. Coral Reefs 8:37-43

Falkowski PG, Dubinsky Z (1981) Light-shade adaptation of Stylophora pistillata, a hermatypic coral from the Gulf of Eilat. Nature 289:172-174

Falkowski PG, Jokiel PL, Kinzie RA (1990) Irradiance and corals. In: Dubinsky Z (ed) Ecosystems of the world 25: coral reefs. Elsevier, Amsterdam, p 89-107
Ferrier-Pagès C, Gattuso JP, Dallot S, Jaubert J (2000) Effect of nutrient enrichment on growth and photosynthesis of the zooxanthellate coral Stylophora pistillata. Coral Reefs 19:103-114

Furla P, Galgani I, Durand I, Allemand D (2000) Sources and mechanisms of inorganic carbon transport for coral calcification and photosynthesis. J Exp Biol 203:3445-3457

Gattuso JP (1987) Ecomorphologie, métabolisme, croissance et calcification du scléractiniaire à zooxanthelles Stylophora pistillata (Golfe D'Aqaba, Mer Rouge) - influence de l'éclairement. PhD thesis, Université d'Aix-Marseille II

Gattuso JP, Jaubert J (1984) Premières données concernant l'action de la lumière sur le métabolisme, la croissance et la calcification in situ du scléractiniaire hermatypique Stylophora pistillata. C R Acad Sci Paris 299:779-783

Gattuso JP, Frankignoulle M, Bourge I, Romaine S, Buddemeier RW (1998) Effect of calcium carbonate saturation of seawater on coral calcification. Global Planet Change 18: $37-46$

Gattuso JP, Allemand D, Frankignoulle M (1999) Photosynthesis and calcification at cellular, organismal and community levels in coral reefs: a review on interactions and control by carbonate chemistry. Am Zool 39:160-183

Gladfelter EH (1983) Spatial and temporal patterns of mitosis in the cells of the axial polyp of the reef coral Acropora cervicornis. Biol Bull 165:811-815

Goiran C, Al-Moghrabi S, Allemand D, Jaubert J (1996) Inorganic carbon uptake for photosynthesis by the symbiotic coral/dinoflagellate association. I. Photosynthetic performances of symbionts and dependence on sea water bicarbonate. J Exp Mar Biol Ecol 199:207-225

Goreau T (1961) Problems of growth and calcium deposition in reef corals. Endeavor 20:32-39

Goreau TF, Goreau NI (1959) The physiology of skeleton formation in corals. II. Calcium deposition by hermatypic corals under various conditions in the reef. Biol Bull 117: $239-250$

Grottoli AG, Wellington GM (1999) Effect of light and zooplankton on skeletal $\delta^{13} \mathrm{C}$ values in the eastern Pacific corals Pavona clavus and Pavona gigantea. Coral Reefs 18: $29-41$

Huston M (1985) Variation in coral growth rates with depth at Discovery Bay. Coral Reefs 4:19-25

Johansen HW (1981) Coralline algae, a first synthesis. CRC Press, Inc., Boca Raton, FL

Johnston IS (1980) The ultrastructure of skeletogenesis in hermatypic corals. Int Rev Cytol 67:171-214

Jokiel PL, Maragos JE, Franzisket L (1978) Coral growth: buoyant weighing technique. In: Stoddart DR, Johannes RE (eds) Coral reefs: research methods. UNESCO, Paris, p 529-541

Kanamori S, Ikegami H (1980) Computer-processed potentiometric titration for the determination of calcium and magnesium in seawater. J Oceanogr Soc Jpn 36:177-184

Kempe S, Kazmierczak J (1994) The role of alkalinity in the evolution of ocean chemistry, organization of living systems, and biocalcification processes. Bull Inst Oceanogr Monaco 13:61-117

Kleypas JA, Buddemeier RW, Archer D, Gattuso JP, Langdon C, Opdyke BN (1999) Geochemical consequences of increased atmospheric carbon dioxide on coral reefs. Nature 284:118-120

Kühl M, Cohen Y, Dalsgaard T, Jørgensen BB, Revsbech NP (1995) Microenvironment and photosynthesis of zooxanthellae in scleractinian corals studied with microsensors for $\mathrm{O}_{2}, \mathrm{pH}$, and light. Mar Ecol Prog Ser 117:159-172

Langdon C, Takahashi T, Marubini F, Atkinson MJ, Sweeney 
C, Aceves H, Barnett H, Chipman D, Goddard J (2000) Effect of calcium carbonate saturation state on the rate of calcification of an experimental coral reef. Global Biogeochem Cycles 14:639-654

Leclercq N (2000) Influence de l'augmentation de la pression partielle de $\mathrm{CO}_{2}$ sur le métabolisme des coraux et des communautés resifales: approche expérimentale. PhD thesis, Université de Paris XI-Orsay

Leclercq N, Gattuso JP, Jaubert J (2000) $\mathrm{CO}_{2}$ partial pressure controls the calcification rate of a coral community. Global Change Biol 6:1-6

Leggat W, Badger MR, Yellowlees D (1999) Evidence for an inorganic carbon-concentrating mechanism in the symbiotic dinoflagellate Symbiodinium sp. Plant Physiol 121: 1247-1255

Logan A, Tomascik T (1991) Extension growth rates in two coral species from high latitude reefs of Bermuda. Coral Reefs 10:155-160

Lough JM, Barnes DJ (1997) Several centuries of variation in skeletal extension, density and calcification in massive Porites colonies from the Great Barrier Reef: a proxy for seawater temperature and a background of variability against which to identify unnatural change. J Exp Mar Biol Ecol 211:29-67

Lough JM, Barnes DJ (2000) Environmental controls on growth of the massive coral Porites. J Exp Mar Biol Ecol 235:225-243

Marubini F, Atkinson MJ (1999) Effects of lowered pH and elevated nitrate on coral calcification. Mar Ecol Prog Ser 188:117-121

Marubini F, Davies PS (1996) Nitrate increases zooxanthellae population density and reduces skeletogenesis in corals. Mar Biol 127:319-328

Marubini F, Thake B (1999) Bicarbonate addition promotes coral growth. Limnol Oceanogr 44:716-720

McCloskey LR, Muscatine L (1984) Production and respiration in the Red Sea coral Stylophora pistillata as a function of depth. Proc R Soc Lond B 222:215-230

Mehrbach C, Culberson CH, Hawley JE, Pytkowicz RM (1973) Meaurement of the apparent dissociaton constants of carbonic acid in seawater at atmospheric pressure. Limnol Oceanogr 18:897-907

Miller MW (1995) Growth of a temperate coral: effects of temperature, light, depth and heterotrophy. Mar Ecol Prog Ser 122:217-225

Editorial responsibility: Otto Kinne (Editor), Oldendorf/Luhe, Germany
Mucci A (1983) The solubility of calcite and aragonite in seawater at various salinities, temperatures and one atmosphere total pressure. Am J Sci 283:780-799

Muscatine L, Falkowski PG, Porter JW, Dubinsky Z (1984) Fate of photosynthetically fixed carbon in light- and shade-adapted colonies of the symbiotic coral Stylophora pistillata. Proc R Soc Lond B 222:181-202

Pearse VB (1970) Incorporation of metabolic $\mathrm{CO}_{2}$ into coral skeleton. Nature 228:383

Porter JW, Muscatine L, Dubinsky Z, Falkowski PG (1984) Primary production and photadaptation in light- and shadeadapted colonies of the symbiotic coral, Stylophora pistillata. Proc R Soc Lond 222:161-180

Rinkevich B, Loya Y (1983) Oriented translocation of energy in grafted reef corals. Coral Reefs 1:243-247

Rinkevich B, Loya Y (1984) Does light enhance calcification in hermatypic corals? Mar Biol 80:1-6

Schneider K, Erez J (2000) Effects of carbonate chemistry on coral calcification, and symbiotic algae photosynthesis and isotopic fractionation. EOS Trans Am Geophys Union (Suppl.) Ocean Sciences Meeting, San Antonio, TX, p 97 (Abstract)

Smith SV, Buddemeier RW (1992) Global change and coral reef ecosystems. Annu Rev Ecol Syst 23:89-118

Smith SV, Pesret F (1974) Processes of carbon dioxide flux in the Fanning Island Lagoon. Pac Sci 28:225-245

Stumm W, Morgan JJ (1981) Aquatic chemistry. An introduction emphasizing chemical equilibria in natural waters, 2nd edn. John Wiley \& Sons, New York

Suzuki A, Nakamori T, Kayanne H (1995) The mechanism of production enhancement in coral reef carbonate systems: model and empirical results. Sediment Geol 99:259-280

Vago R, Dubinsky Z, Genin A, Ben-Zion M, Kizner Z (1997) Growth rates for three symbiotic corals in the Red Sea. Limnol Oceanogr 42:1814-1819

Vaughan TW (1919) Corals and the formation of coral reefs. Annu Rep Smithson Inst 17:189-238

Walsh TW (1989) Total dissolved N in seawater: a new high temperature combustion method and a comparison with photo-oxidation. Mar Chem 26:295-311

Witting J (1999) Coral heterotrphic nutrition and effects on growth. PhD thesis, Northeastern University, Boston

Yap HT, Alvarez RM, Custodio HM, Dizon RM (1998) Physiological and ecological aspects of coral transplantation. J Exp Mar Biol Ecol 229:69-84

Submitted: August 14, 2000; Accepted: January 17, 2001 Proofs received from author(s): September 13, 2001 